\title{
Article
}

\section{Are hydrogen peroxide, hypochlorite and peracetic acid potential}

\section{endocrine disruptors?}

Shu-shu Zhonga ${ }^{\text {a }}$ Jun Zhang a , Ze-hua Liu ${ }^{\text {a,b,c,d, * }}$, Zhi Dang a , Yu Liu ${ }^{\text {e,f }}$

a School of Environment and Energy, South China University of Technology, Guangzhou, 510006; Guangdong, China

${ }^{\mathrm{b}}$ Key Lab Pollution Control \& Ecosystem Restoration in Industry Cluster, Ministry of Education, Guangzhou, 510006; Guangdong, China

c Guangdong Provincial Key Laboratory of Solid Wastes Pollution Control and Recycling, Guangzhou, 510006; Guangdong, China

d Guangdong Provincial Engineering and Technology Research Center for Environment Risk Prevention and Emergency Disposal, South China University of Technology, Guangzhou, 510006; Guangdong, China

e Advanced Environmental Biotechnology Center, Nanyang Environment and Water Research Institute, Nanyang Technological University, CleanTech one, Singapore 637141

${ }^{\mathrm{f}}$ School of Civil and Environmental Engineering, Nanyang Technological University, Singapore 639798

* Corresponding author e-mail: zehualiu@sscut.edu.cn; Tel: +86-20-39380508

\begin{abstract}
Arylsulfatase and $\beta$-glucuronidase are two important enzymes in human, which play important role on dynamic equilibrium of steroidal estrogens. This work probably for the first time reported that hydrogen peroxide $\left(\mathrm{H}_{2} \mathrm{O}_{2}\right)$, hypochlorite and peracetic acid (PAA) could effectively inhibit the activities of arylsulfatase and/or $\beta$-glucuronidase. The 50 percent of inhibitions $\left(\mathrm{IC}_{50}\right)$ of $\mathrm{H}_{2} \mathrm{O}_{2}$, and PAA on arylsulfatase were found to be $142.90 \pm 9.00,91.83 \pm 10.01$, and $43.46 \pm 2.92 \mu \mathrm{M}$, respectively. The corresponding respective $\mathrm{IC}_{50}$ of hypochlorite and PAA on $\beta$-glucuronidase were $704.90 \pm 41.40$ and $23.26 \pm 0.82 \mu \mathrm{M}$, while $\mathrm{H}_{2} \mathrm{O}_{2}$ showed no inhibition on $\beta$-glucuronidase. It was further revealed that the inhibition of hypochlorite on both arylsulfatase and $\beta$-glucuronidase was irreversible. On the contrary, the inhibition by $\mathrm{H}_{2} \mathrm{O}_{2}$ and PAA was reversible. Moreover, it was found that the inhibitions of arylsulfatase and/or $\beta$-glucuronidase by these three chemicals were pH-dependent, among which the inhibition by $\mathrm{H}_{2} \mathrm{O}_{2}$ was competitive and non-competitive for PAA. In general, $\mathrm{H}_{2} \mathrm{O}_{2}$ and hypochlorite can be endogenously produced in human, which suggested that the two compounds are potential endocrine disruption compounds (EDCs) as they can cause endocrine disruption via inhibition of arylsulfatase and $\beta$-glucuronidase. This work further indicated that any agent that can
\end{abstract}


induce production of $\mathrm{H}_{2} \mathrm{O}_{2}$ or hypochlorite in human is potential EDC, which explains why some EDCs with very weak or no estrogenic potency can cause endocrine disruption that confirmed in epidemiological studies.

Keywords: Arylsulfatase; $\beta$-glucuronidase; Hydrogen peroxide;

Hypochlorite; Inhibition

\section{Introduction}

Arylsulfatase and $\beta$-glucuronidase have been widely present in many organisms including humans, which are able to catalyze the hydrolysis of sulfates/glucuronides (Dzialoszynski et al., 1967; Meroni et al., 1997; Posey et al, 1977; Taha et al., 2019a). The important physiological functions of the two enzymes are to maintain dynamic equilibrium of natural estrogens in human body. Normally, only about 2 to 3 percent of natural estrogens are free estrogens in human, while the rest are sulfate or glucuronide form (Gruber et al., 2002; Zhao et al., 2014). The free natural estrogens play important roles in stimulating growth, blood flow, water retention in sexual organs, neuro and vaso protection, reduction of bone loss, while the conjugated estrogens act as reservoir (Gruber et al., 2002; Reed et al., 2005). Natural free estrogens in human are accurately regulated, and once the equilibrium was disrupted this may trigger severe outcome. For example, humans with significantly higher urinary arylsulfatase/ $\beta$-glucuronidase activity results in higher free estrogens in body, which have been thought to be the main reason for the development of many cancers including breast cancer, stomach cancer, ovarian cancer, colonic cancer, etc.(Almandil et al., 2019; Chapman et al., 2002; Rath et al., 2004; Taha et al., 2019b). Therefore, inhibition of arylsulfatase/ $\beta$-glucuronidase had been explored as one of the effective strategies for such cancer treatment, among which STX64 has been applied in clinical trials (Walaszek et al., 1990; Reed et al., 2005).

Arylsulfatase and $\beta$-glucuronidase have been reported to be two extreme enzymes, which can endure high concentrations of mercury dichloride, sodium azide, ethanol and EDTA (Zhang et al., 2020). As sanitizers for various medical and non-medical applications, $\mathrm{H}_{2} \mathrm{O}_{2}$, hypochlorite, and PAA have been commonly used (Hidalgo et al., 2002; Huang et al., 2004; Hugo et al., 1995; Loo et al., 2012) . Among these, $\mathrm{H}_{2} \mathrm{O}_{2}$ and hypochlorite are also important compounds, which can be endogenously produced by cellular enzymatic reactions in human, which are important signal biomarker in human (Bekeschus et al., 2014; Forman et al., 2016;Koide et al., 2011; Sato et al., 2013). This work is the first to report that $\mathrm{H}_{2} \mathrm{O}_{2}$, hypochlorite and PAA can effectively inhibit arylsulfatase and/or $\beta$-glucuronidase, which may indicate important physiological functions. 


\section{Materials and Methods}

\subsection{Enzymes and chemicals}

Potassium 4-nitrophenyl sulfate $\quad(p$ NPS, purity $>98 \%)$, 4-Nitrophenyl- $\beta$-D-glucuronide ( $p$ NPG, purity $>98 \%)$ and p-nitrophenol ( $p$ NP, spectrophotometric grade), arylsulfatase ( $\geq 10,000$ units/g solid) from Helix pomatia (Type H-1, catalogue number: S9626), $\beta$-glucuronidase ( $\geq 100,000$ units/g solid) from Helix pomatia (Type H-1, catalogue number: G0751) were purchased from Sigma-Aldrich (Shanghai, China). $\mathrm{H}_{2} \mathrm{O}_{2}(30 \%)$ was purchased from Guangzhou chemical reagent factory (Guangzhou, China). $\mathrm{NaClO}$ (available chlorine, 8.0\%, w/w) was purchased from ANPEL (Shanghai, China). The NaClO concentration was calibrated with the standard method of GB/T 19106 (2013). PAA (13\%, w/w) including solution I and II was purchased from GHTECH (Shantou, China). Before using, fresh PPA was obtained by mixing the solution I and II in the proportion of 1:1 (v/v), and it was used within 2 days. This PAA concentration was calibrated according to the standard method of GB/T 19104 (2008). The other reagents not listed were purchased from Aladdin (Shanghai, China).

Stock solutions of arylsulfatase and $\beta$-glucuronidase were prepared at the concentration of $10 \mathrm{U} / \mathrm{mL}$ by dissolving enzyme powder into $0.5 \mathrm{M}$ Tris-HCl buffer $(\mathrm{pH}=7.0)$. The $p$ NPS stock solution was prepared with $0.5 \mathrm{M}$ acetate buffer ( $\mathrm{pH} 5.8$ ), while $p$ NPG was prepared with $0.5 \mathrm{M}$ phosphate buffer (pH 7.0), both of which were at a concentrations of $5 \mathrm{mM}$. All solutions were prepared with reagent grade chemicals and ultrapure water $(18.2 \mathrm{M} \Omega / \mathrm{cm})$.

\subsection{Enzyme activity}

The activity of arylsulfatase was measured according to Zhang et al. (2020). In simple, the arylsulfatase activity was determined by measuring the amount of $p \mathrm{NP}$ produced from $p$ NPS. In the analysis, the assay mixture solution $(3 \mathrm{~mL})$ containing $0.5 \mathrm{~mL}$ diluted arylsulfatase enzyme, $0.5 \mathrm{~mL}$ of $5 \mathrm{mM} p \mathrm{NPS}$, and $2 \mathrm{~mL}$ of $0.5 \mathrm{M}$ acetate buffer $(\mathrm{pH}=5.8)$ was incubated at $37^{\circ} \mathrm{C}$ for $1 \mathrm{~h}$. The reaction was stopped by adding $2 \mathrm{~mL}$ of $0.5 \mathrm{M} \mathrm{NaOH}$ solution to the mixture, and the $p \mathrm{NP}$ released from the $p$ NPS was quantified spectrophotometrically at a wavelength of $400 \mathrm{~nm}$ (UV spectrophotometer, CANY 723, Shanghai, China). Each experiment was performed in triplicate.

The $\beta$-glucuronidase activity was determined according to the method described in Zhang et al. (2020). Briefly, the $\beta$-glucuronidase activity was determined by measuring the amount of $p \mathrm{NP}$ released from $p$ NPG. The reaction mixture solution (1 $\mathrm{mL}$ ), contained $0.6 \mathrm{~mL}$ of $0.1 \mathrm{M}$ phosphate buffer $(\mathrm{pH} 7.0), 0.2 \mathrm{~mL}$ diluted $\beta$-glucuronidase enzyme and $0.2 \mathrm{~mL}$ of $5 \mathrm{mM} p \mathrm{NPG}$. The above reaction mixture solution was incubated for $1 \mathrm{~h}$ at $37^{\circ} \mathrm{C}$. The reaction was stopped by adding $1 \mathrm{~mL}$ of $0.5 \mathrm{M} \mathrm{NaOH}$ and the $p \mathrm{NP}$ deconjugated from $p \mathrm{NPG}$ was quantified spectrophotometrically at a wavelength of $400 \mathrm{~nm}$. Each experiment was performed in triplicate. 
Arylsulfatase/ $\beta$-glucuronidase enzyme activity (U) was defined as the absorbance equivalent of $1 \mu \mathrm{mol} p \mathrm{NP}$ produced per hour per milliliter of enzyme solution at $37^{\circ} \mathrm{C}$. For the convenience of comparison, relative activity is used, and the maximal enzyme activity is arbitrarily set to $100 \%$. Limit of detection (LOD) of the spectrophotometric method was calculated according to the three times of the standard deviation (SD), which was obtained from nine repeated determinations of the lowest $p$ NP concentration used for the standard calibration curve (Yuan et al., 2016; 2017). LOD of this method for $p \mathrm{NP}$ was $31 \mu \mathrm{g} / \mathrm{L}$, which is equal to $0.22 \mathrm{U} / \mathrm{L}$ for arylsulfatase and $\beta$-glucuronidase.

\subsection{Inhibitory assays}

Inhibition experiments on arylsulfatase or $\beta$-glucuronidase by different inhibitors were performed with different concentrations, and the inhibitor solution was freshly prepared before use. For arylsulfatase inhibition experiment, the reaction mixture solution $(3.5 \mathrm{~mL})$ contained $2 \mathrm{~mL}$ of $0.1 \mathrm{M}$ acetate buffer $(\mathrm{pH} 5.8), 0.5 \mathrm{~mL}$ of diluted arylsulfatase enzyme, $0.5 \mathrm{~mL}$ of $5 \mathrm{mM} p$ NPS and $0.5 \mathrm{~mL}$ of water as the control or $0.5 \mathrm{~mL}$ of inhibitor $\left(\mathrm{H}_{2} \mathrm{O}_{2}, \mathrm{NaClO}\right.$ or PAA) with different concentrations. The addition concentrations of $\mathrm{H}_{2} \mathrm{O}_{2}$ and $\mathrm{NaClO}$ in the reaction mixture were 1, 5, 10, 50, 100, 500, 1000,5000 , and $10000 \mu \mathrm{M}$, respectively, while the concentrations of PAA were 1, 5, $10,50,100,500$, and $1000 \mu \mathrm{M}$, respectively. The reaction mixture solution was mixed and incubated for $1 \mathrm{~h}$ at $37{ }^{\circ} \mathrm{C}$. The $p$ NP deconjugated from $p$ NPS was measured at a wave length of $400 \mathrm{~nm}$ after the reaction was stopped by adding $1.5 \mathrm{~mL}$ of $0.5 \mathrm{M}$ $\mathrm{NaOH}$. Each experiment was performed in triplicate.

For $\beta$-glucuronidase inhibition experiment, the reaction mixture solution $(1.2 \mathrm{~mL})$ contained $0.6 \mathrm{~mL}$ of $0.1 \mathrm{M}$ phosphate buffer ( $\mathrm{pH} 7.0$ ), $0.2 \mathrm{~mL}$ of diluted arylsulfatase enzyme, $0.2 \mathrm{~mL}$ of $5 \mathrm{mM} p \mathrm{NPG}$ and $0.2 \mathrm{~mL}$ of water as the control or $0.2 \mathrm{~mL}$ of $\mathrm{H}_{2} \mathrm{O}_{2}$, $\mathrm{NaClO}$ or PAA. The addition concentrations of $\mathrm{H}_{2} \mathrm{O}_{2}$ in the reaction mixture were 1,5 , $10,50,100,500,1000,5000$, and $10000 \mu \mathrm{M}$, respectively, while the concentrations of $\mathrm{NaClO}$ and PAA were the same with $1,5,10,50,100,500$, and $1000 \mu \mathrm{M}$, respectively. The reaction mixture solution was mixed and incubated for $1 \mathrm{~h}$ at $37^{\circ} \mathrm{C}$. The $p \mathrm{NP}$ deconjugated from $p$ NPG was measured at a wave length of $400 \mathrm{~nm}$ after the reaction was stopped by adding $0.8 \mathrm{~mL}$ of $0.5 \mathrm{M} \mathrm{NaOH}$. Each experiment was performed in triplicate.

To check the inhibition differences at different $\mathrm{pH}$ conditions, different buffer solutions were used as listed. 0.1 M acetate buffer ( $\mathrm{pH}$ 5.0-5.8), $0.1 \mathrm{M}$ citric acid/0.1 $\mathrm{M}$ sodium citrate ( $\mathrm{pH} 5.0-6.0), 0.5 \mathrm{M}$ Tris- $\mathrm{HCl}(\mathrm{pH} 7.0-8.0)$, and $0.1 \mathrm{M}$ phosphate buffer (pH 6.0-8.0).

Inhibition percent was calculated as shown in equation (1):

$$
\mathrm{I}(\%)=100-100 *(\mathrm{~A} / \mathrm{C})
$$

Where $\mathrm{I}$ is the inhibition percent of the enzyme activity by an inhibitor, A is the measured enzyme activity with an inhibitor at different concentrations, $\mathrm{C}$ is the measured activity without addition of an inhibitor. Inhibition dose-response curve was plotted with Graphpad Prism 8 software, and $\mathrm{IC}_{50}$ was simultaneously obtained, which 
means the half inhibition concentration of an inhibitor.

\section{Results}

\subsection{Inhibition dose-response curves}

Figures 1 and 2 showed the inhibition dose-response curves of $\mathrm{H}_{2} \mathrm{O}_{2}$, hypochlorite and PAA on arysulfatase and $\beta$-glucuronidase. It is evident that hypochlorite and PAA could effectively inhibit both arysulfatase and $\beta$-glucuronidase, while $\mathrm{H}_{2} \mathrm{O}_{2}$ was only effective for inhibiting arylsulfatase. The respective $\mathrm{IC}_{50}$ of $\mathrm{H}_{2} \mathrm{O}_{2}$, hypochlorite, and PAA on arylsulfatase were determined to be $142.90 \pm 9.00,91.83 \pm 10.01$, and $43.46 \pm$

$2.92 \mu \mathrm{M}$, while $704.90 \pm 41.40$ and $23.26 \pm 0.82 \mu \mathrm{M}$ for the inhibition of $\beta$-glucuronidase for hypochlorite and PAA. These clearly suggested that PAA had the strongest inhibitory effect on arylsulfatase, follows by hypochlorite, with $\mathrm{H}_{2} \mathrm{O}_{2}$ being the least. Meanwhile, the inhibitory effect of PAA on $\beta$-glucuronidase was much stronger than that of hypochlorite. Interestingly, the inhibitory effect of hypochlorite on arylsulfatase was significantly stronger than that on $\beta$-glucuronidase. In contrast, the inhibitory effect of PAA on $\beta$-glucuronidase appeared to be stronger than that on arylsulfatase. However, it should be noted that the maximum inhibition degree of PAA on $\beta$-glucuronidase was only about $60 \%$.

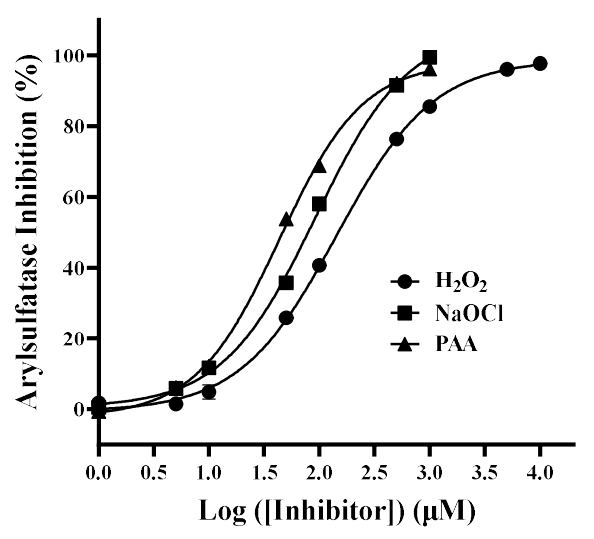

Fig. 1 Dose-response curves of $\mathrm{H}_{2} \mathrm{O}_{2}, \mathrm{NaClO}$ and PAA on arylsulfatase 


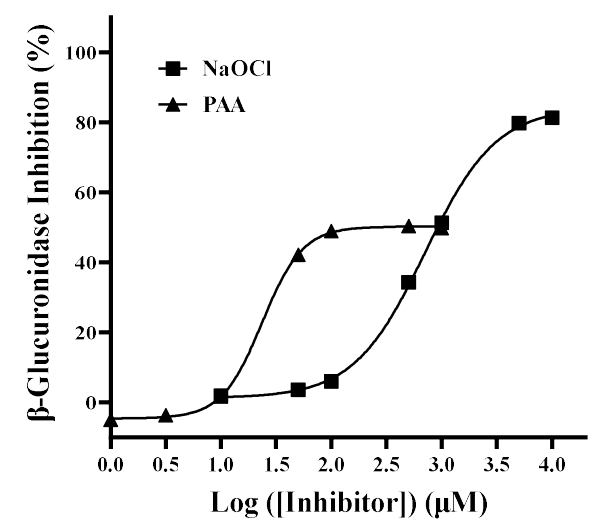

Fig. 2 Dose-response curves of $\mathrm{NaClO}$ and PAA on $\beta$-glucuronidase. Data for $\mathrm{H}_{2} \mathrm{O}_{2}$ is not drawn as it showed no inhibition on $\beta$-glucuronidase.

\subsection{Effect of pH on enzyme inhibition}

As $\mathrm{H}_{2} \mathrm{O}_{2}$ and PAA belong to weak acids and hypochlorite is a weak alkaline, it is reasonable to consider that their dissociation degrees are all $\mathrm{pH}$-dependent, and subsequently affect their inhibitory powers to arysulfatase and $\beta$-glucuronidase. On the other hand, it has been known that both arysulfatase and $\beta$-glucuronidase could be completely inhibited at high above 11 or below 3 (Zhang et al., 2020). Thus, in this study, the $\mathrm{pH}$ studied was controlled in the range of 5-8. As can be seen in Fig. 3, there was no significant differences in the inhibition of arylsulfatase by $\mathrm{H}_{2} \mathrm{O}_{2}$ in the $\mathrm{pH}$ range of 5 to 7 , while reduced inhibition was observed under weak alkaline condition of $\mathrm{pH} 8$.

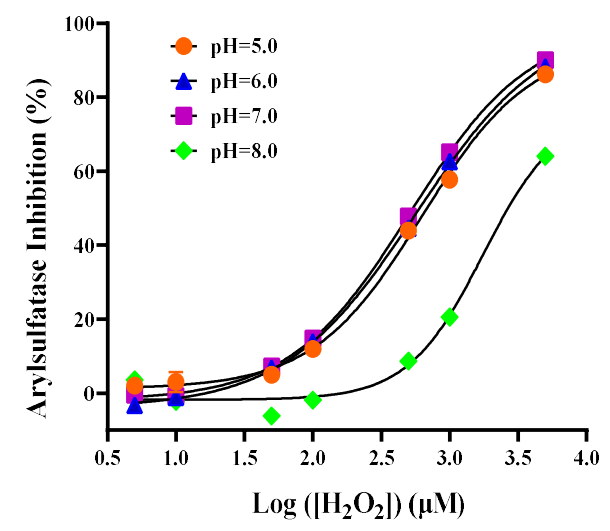

Fig. 3 Dose-response curves of $\mathrm{H}_{2} \mathrm{O}_{2}$ on arylsulfatase under different $\mathrm{pH}$ conditions.

Under acidic condition, hypochlorite can react with hydrogen ion by forming hypochlorous acid $(\mathrm{HOCl})$ which may have different inhibition power to of the enzymes studied (data is not shown). It appears from Fig. 4A that the inhibition of 
hypochlorite on arylsulfatase was much stronger at $\mathrm{pH}=5.0$ than at $\mathrm{pH}=5.8$. Moreover, its $\mathrm{IC}_{50}$ at $\mathrm{pH}=5.0$ (i.e. $7.64 \pm 0.61 \mu \mathrm{M}$ ) was 12 times lower than that at $\mathrm{pH}=5.8$ (i.e.

$91.83 \pm 10.01 \mu \mathrm{M})$. Similar trend was observed in Fig. 4B for $\beta$-glucuronidase. These seemed to suggest that acidic condition was making hypochlorite more inhibitory towards arysulfatase and $\beta$-glucuronidase. The inhibitory effects of PAA on arylsulfatase at different $\mathrm{pH}$ were shown in Fig. 5. It seemed that inhibition tended to decrease with increasing $\mathrm{pH}$, e.g. nearly no inhibition was observed at $\mathrm{pH} 8$ with a PAA concentration below $1 \mathrm{mM}$. Similar to arylsulfatase, the inhibitory of PAA on $\beta$-glucuronidase was insignificant at $\mathrm{pH} 5$ and 6 (Fig. 5B).
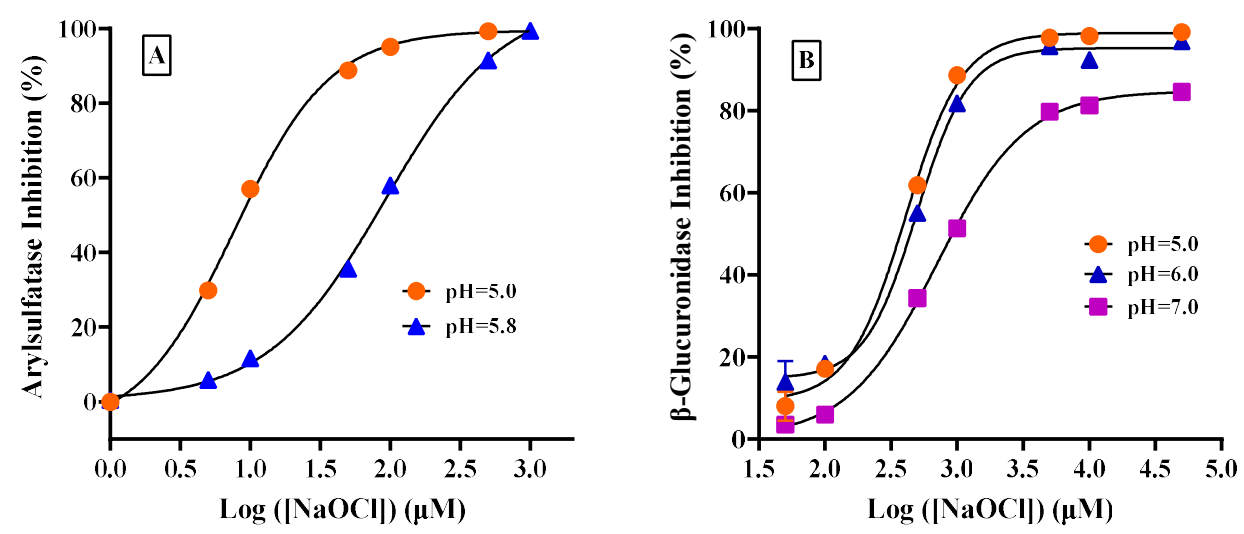

Fig. 4 Dose-response curves of $\mathrm{NaClO}$ on arylsulfatase (A) and $\beta$-glucuronidase (B) under different $\mathrm{pH}$ conditions.
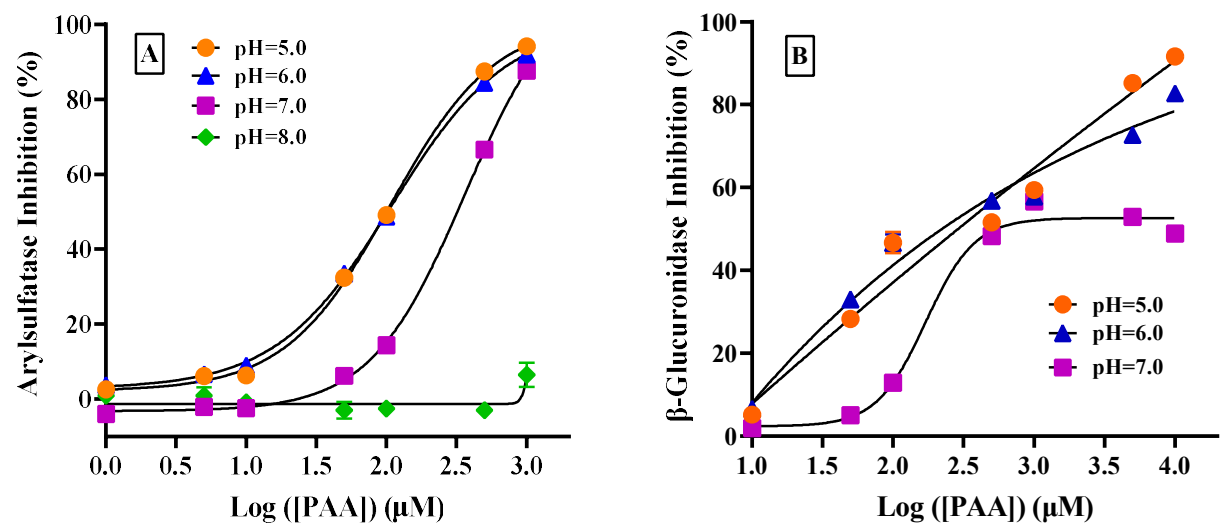

Fig. 5 Dose-response curves of PAA on arylsulfatase (A) and $\beta$-glucuronidase (B) under different $\mathrm{pH}$ conditions. 


\subsection{Inhibition mechanism}

To explore possible inhibition mechanisms of arysulfatase and $\beta$-glucuronidase by $\mathrm{H} 2 \mathrm{O} 2$, hypochlorite and PAA at different $\mathrm{pH}$, the relationship between enzyme activity and individual inhibitor concentration was presented in Fig 6. It was found that the inhibitions of $\mathrm{H}_{2} \mathrm{O}_{2}$ and PAA on arylsulfatase should be reversible, while the inhibition of hypochlorite on arylsulfatase was irreversible. Similar to arylsulfatase, the inhibition of PAA on $\beta$-glucuronidase was reversible, while the inhibition of hypochlorite was irreversible. To further determine the inhibition kinetics, Lineweaver-Burk plot was plotted in Fig.7, showing that the inhibition on arylsulfatase by $\mathrm{H} 2 \mathrm{O} 2$ was competitive, while non-competitive for the inhibitions of PAA on arylsulfatase and $\beta$-glucuronidase.

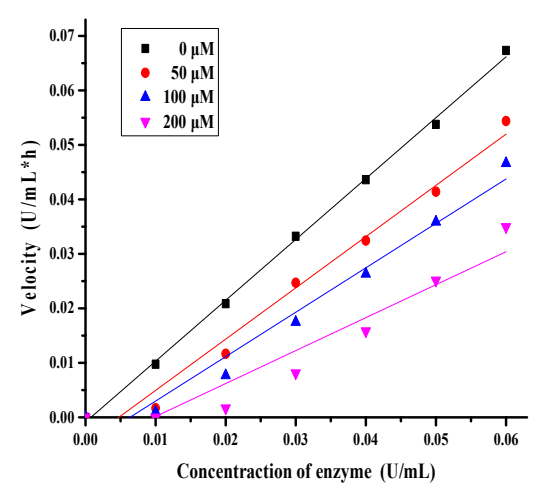

$\mathrm{NaOCl}$ — Arylsulfatase

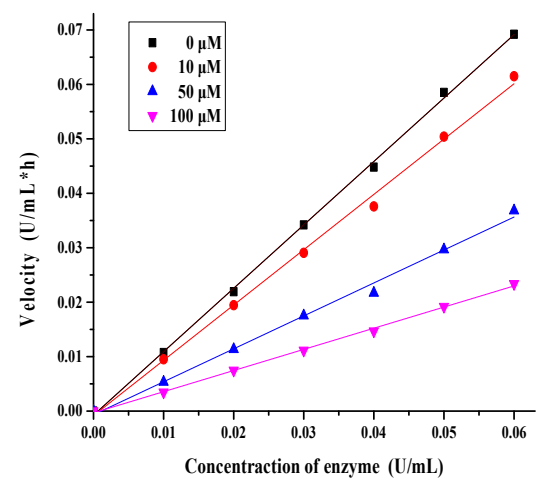

PAA — Arylsulfatase

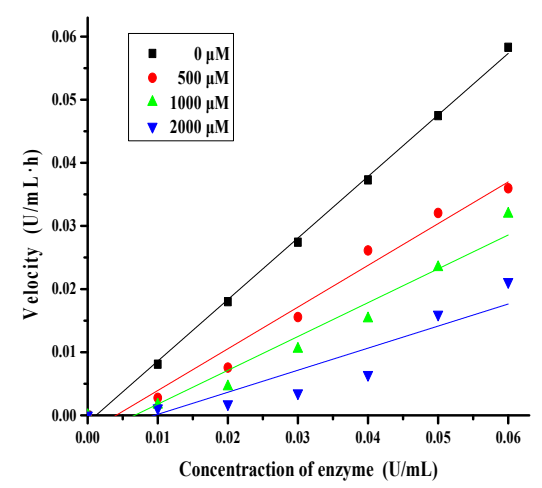

$\mathrm{NaOCl} \_\beta$-Glucuronidase

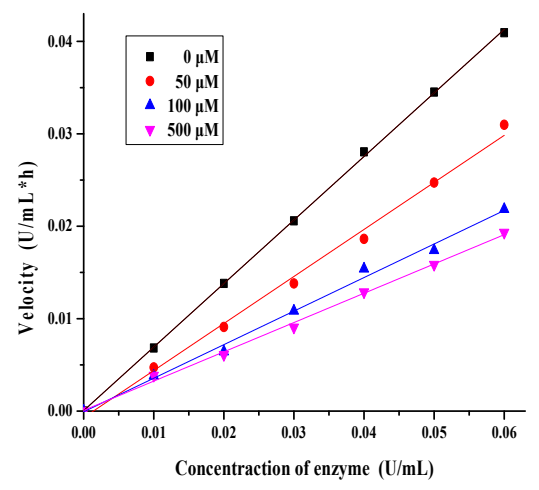

PAA — $\beta$-Glucuronidase 


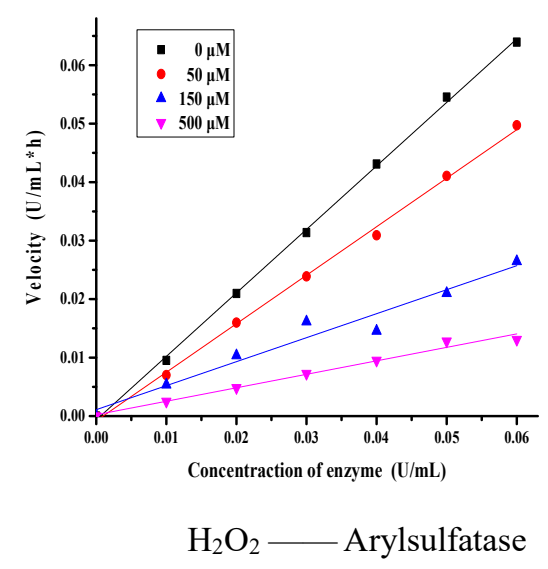

Fig. 6 Inhibitions of $\mathrm{H}_{2} \mathrm{O}_{2}, \mathrm{NaClO}$ and PAA with different concentrations on arylsulfatase and/ or $\beta$-glucuronidase.
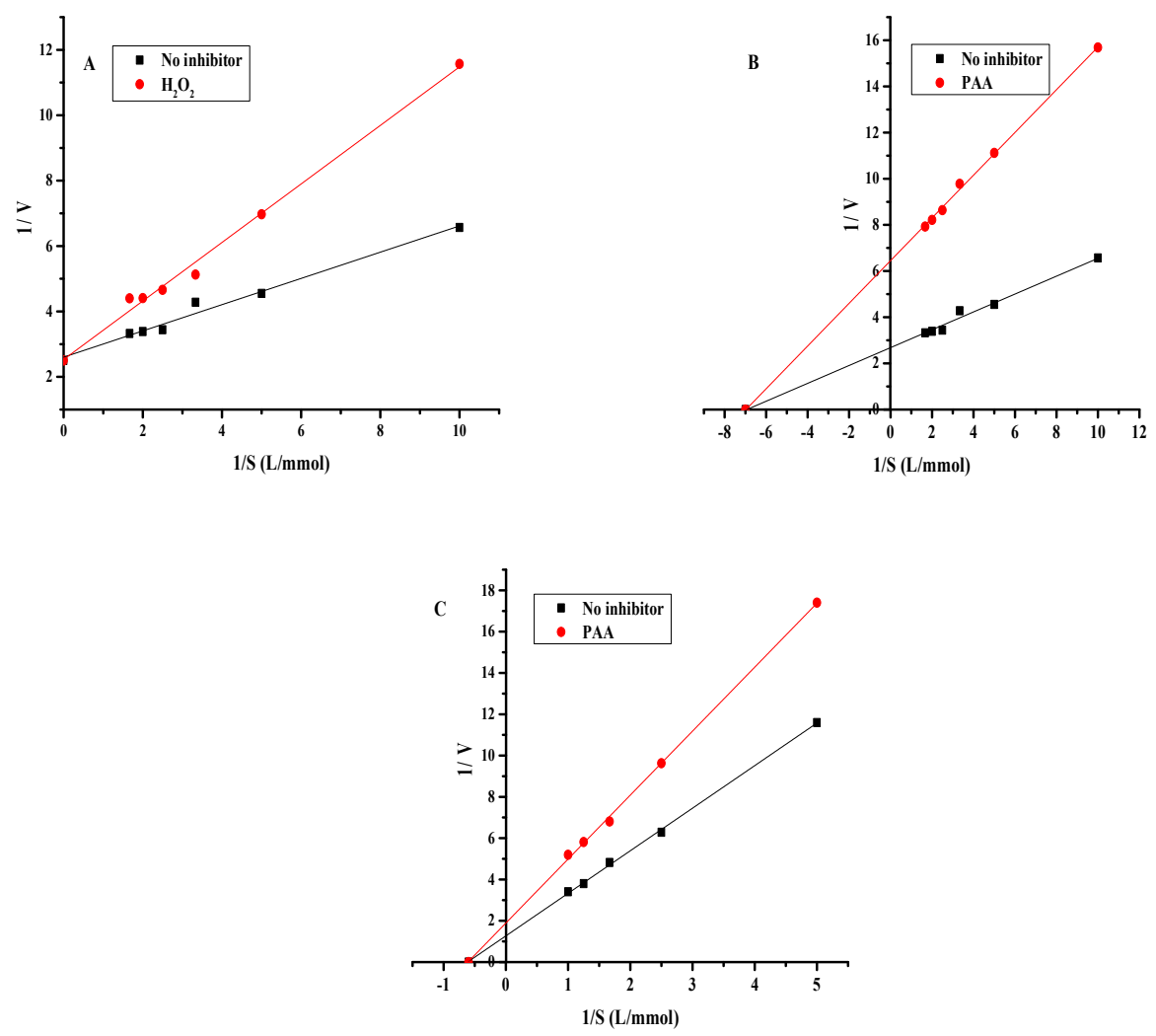

Fig. 7 Lineweaver-Burk plots of the inhibition reaction of arylsulfatase in the presence of $\mathrm{H}_{2} \mathrm{O}_{2}$ (A), PAA (B). Lineweaver-Burk plots of the inhibition reaction of $\beta$-glucuronidase in the presence of PAA $(\mathrm{C})$. 


\subsection{Significance of this work}

Endocrine disrupting compounds (EDCs) are, by definition, natural or synthetic agents that can mimic, enhance, or inhibit the action of endogenous hormones that are responsible for maintaining homeostasis and controlling normal development (Melnick, 1999; U.SEPA, 1997). The most commonly investigated EDCs are those that can mimic the effects of steroid hormones, which often show different estrogenic potencies that can be determined with different bioassays (Bovee et al., 2004; Liu et al., 2009; 2010). With the definition of estrogenic potency, it is convenient to identify which are strong EDCs, while which are weak. The potential adverse effect of each EDC depends on both its estrogenic potency and concentration, thus the concept of estrogen equivalence (EEQ) has been widely adopted (Luo et al., 2018; 2020; Wang et al., 2020).. This above criterion well describes the potential adverse effect of one individual EDC at any given concentration. However, many EDCs cannot be well explained with the above conception. For example, di-2-(ethyl hexyl) phthalate, well-known as DEHP, the estrogenic potency of which was as low as $10^{-7}$, suggesting an extremely weak EDC (Luo et al., 2018). Considering its possible human exposure level to normal population, DEHP as an EDC unlikely pose potential adverse effects to human. Nevertheless, epidemiological studies have shown that DEHP can pose different adverse effects on human including reproductive, developmental and cardiovascular systems (Benjamin et al., 2017; Kay et al., 2013; Mariana et al., 2016; Mathieu-Denoncourt et al., 2015).. Another example is cadmium, which possesses no estrogenic potency at all, but it is a well-known EDC (Luo et al., 2014; Paschoalini et al., 2019; Stasenko et al., 2010).

Many studies have shown that both DEHP and cadmium could induce production of $\mathrm{H}_{2} \mathrm{O}_{2}$ in human (Ghosh etal., 2010; Mates et al., 2010; Matovic et al.,2015; Shen et al., 2019; Szymanska-Chabowska et al., 2009), while existence of $\mathrm{H}_{2} \mathrm{O}_{2}$ can further induce hypochlorite (Yap et al., 2007). Based on the fact that $\mathrm{H}_{2} \mathrm{O}_{2}$ and hypochlorite can effectively inhibit arylsulfatase and/or $\beta$-glucuronidase, this may suggest that DEHP and cadmium can disturb human endocrine system via production of $\mathrm{H}_{2} \mathrm{O}_{2}$ and hypochlorite. This may well explain why DEHP and cadmium with very weak or no estrogenic potency can act as two EDCs that can pose adverse effects to human. Not limited to DEHP and cadmium, any agent that can induce production of $\mathrm{H}_{2} \mathrm{O}_{2}$ and hypochlorite in human or animals is potential EDC.

Table 1 Hydrogen peroxide in human reported by different studies

\begin{tabular}{|c|c|c|c|c|c|}
\hline Number & Objective & $\begin{array}{c}\text { Sample } \\
\text { type }\end{array}$ & $\begin{array}{c}\text { Sample } \\
\text { size }\end{array}$ & $\begin{array}{c}\text { Concentration } \\
(\mu \mathrm{M})\end{array}$ & Reference \\
\hline 1 & Man & Plasma & 1 & 4.825 & Yamamoto et al., 1987 \\
\hline 2 & Man & Plasma & 1 & 5.5 & $\begin{array}{c}\text { Yamamoto and Ames, } \\
1987\end{array}$ \\
\hline 3 & Men & Plasma & 17 & $5.85-7.15$ & Deskur et al., 1998 \\
\hline 4 & Men & Plasma & 50 & $2.14-3.15$ & Lacy et al., 1998a \\
\hline 5 & Men and women & Plasma & 236 & $0.61-6.79$ & Lacy et al., 1998b \\
\hline
\end{tabular}




\begin{tabular}{|c|c|c|c|c|c|}
\hline 6 & Children & Plasma & -- & $1.4-2$ & Li et al., 2010 \\
\hline 7 & Men and Women & Plasma & 60 & $2.5-6.2$ & Banerjee et al., 2003 \\
\hline 8 & Men and Women & Plasma & 30 & $21-113$ & $\begin{array}{c}\text { Eierusz-Wysocka et al., } \\
1995\end{array}$ \\
\hline 9 & Men and Women & Plasma & 53 & $30.5-50.3$ & Kazmierczak et al., 1995 \\
\hline 10 & Pregnant women & Plasma & 31 & $50.1-66.9$ & Tsukimori et al., 2008 \\
\hline 11 & Men & Blood & 6 & $114-577(288)$ & Varma et al., 1990 \\
\hline 12 & Men & Plasma & 6 & $13-57(34)$ & Varma et al., 1990 \\
\hline
\end{tabular}

Considering the importance of $\mathrm{H}_{2} \mathrm{O}_{2}$ and hypochlorite in human body, studies relating their human blood concentration were summarized. As shown in Table 1, the reported concentrations of $\mathrm{H}_{2} \mathrm{O}_{2}$ in human blood samples varied greatly, which ranged from 0.1-6050 $\mu \mathrm{M}$. Among these, some exceeded the $\mathrm{IC}_{50}$ that reported in this work for arylsulfatase and $\beta$-glucuronidase, which clearly suggest that $\mathrm{H}_{2} \mathrm{O}_{2}$ in human body can act as an EDC via inhibition of arylsulfatase. Compared to $\mathrm{H}_{2} \mathrm{O}_{2}$, hypochlorite showed much stronger inhibition to arylsulfatase, and showed simultaneously inhibition to $\beta$-glucuronidase, which are all $\mathrm{pH}$-dependent. As hypochlorite can also be endogenously produced through peroxidation of chloride ion by the catalysis of enzyme myeloperoxidase in leukocytes including macrophages, monocytes and neutrophils, the adverse effect of any potential EDC via induction of $\mathrm{H}_{2} \mathrm{O}_{2}$ and hypochlorite, is likely enhanced when production of hypochlorite is at more favorable condition. It should be noted that due to instability of $\mathrm{H}_{2} \mathrm{O}_{2}$ in human blood as well as the matrix interferences, not all the concentration data summarized in Table 1 is corrected (Forman et al., 2016). However, it is still believable that $\mathrm{H}_{2} \mathrm{O}_{2}$ and hypochlorite in human can act as two special EDCs via inhibition of arylsulfatase and/or $\beta$-glucuronidase, which further suggests that any agent that can induce production of $\mathrm{H}_{2} \mathrm{O}_{2}$ or hypochlorite is potential EDC. To the best of our knowledge, this is the first report that $\mathrm{H}_{2} \mathrm{O}_{2}$, hypochlorite, and PAA can effectively inhibit arylsulfatase and/or $\beta$-glucuronidase, which further suggest some EDCs may act as endocrine disruptors via induction of $\mathrm{H}_{2} \mathrm{O}_{2}$ and hypochlorite.

\section{Conclusions}

It was demonstrated for the first time that $\mathrm{H}_{2} \mathrm{O}_{2}$, hypochlorite, and PAA could effectively inhibit arylsulfatase and/or $\beta$-glucuronidase. The following conclusions can be drawn.

1) Hypochlorite and PAA at the concentration level of $\mu \mathrm{m}$ could significantly inhibit both arylsulfatase and $\beta$-glucuronidase, while $\mathrm{H}_{2} \mathrm{O}_{2}$ was only effective for inhibiting arylsulfatase.

2) The inhibition of $\mathrm{H}_{2} \mathrm{O}_{2}$ and PAA to arylsulfatase and $\beta$-glucuronidase was found to be reversible, while irreversible inhibition for hypochlorite.

3) $\mathrm{H}_{2} \mathrm{O}_{2}$, hypochlorite, and PAA may behave as special endocrine disruptors through 
inhibition of arylsulfatase and/or $\beta$-glucuronidase. This indeed led to extended family of known endocrine disruptors.

\section{Declaration of interest}

The authors declare that there is no conflict of interest that could be perceived as prejudicing the impartiality of the research reported.

\section{Acknowledgement}

This work was financially supported by the Program for National Natural Science Foundation of China (No.21577040; No. 21107025); Science and Technology Program of Guangzhou, China (No.201904010100; No. 201510010162); Special funds for public welfare research and capacity building in Guangdong Province (No.2015A020215003) as well as the Guangdong Science and Technology Program (2020B121201003).

\section{References}

Almandil NB, Taha M, Gollapalli M, Rahim F, Ibrahim M, Mosaddik A, Anouar E, Indole bearing thiadiazole analogs: synthesis, beta-glucuronidase inhibition and molecular docking study. BMC Chemistry. (2019);13: 14.

Banerjee D, Madhusoodannan UK, Nayak S, Jacob J. Urinary hydrogen peroxide: a probable marker of oxidative stress in malignancy. Clinica Chimica Acta, 2003; 334:205-209.

Bekeschus S, Kolata, J, Winterbourn C, Kramer A, Turner R, Weltmann KD, Broker B, Masur K. Hydrogen peroxide: A central player in physical plasma-induced oxidative stress in human blood cells. Free Radical Research, 2014; 48:542-549.

Benjamin S, Masai E, Kamimura N, Takahashi K, Anderson RC, Faisal PA. Phthalates impact human health: Epidemiological evidences and plausible mechanism of action. Journal of Hazardous Materials, 2017; 340:360-383.

Bovee TFH, Helsdingen RJR, Rietjens IMCM, Keijer J, Hoogenboom RLAP. Rapid yeast bioassays stably expressing human estrogen receptors $\alpha$ and $\beta$ and green fluorescent protein: A comparison of different compounds with both receptor types. Journal of Steroid Biochemistry and Molecular Biology, 2004; 91: 99-109.

Chapman E, Ding S, Schultz PG, Wong CH. A potent and highly selective sulfotransferase inhibitor. Journal of American Chemical Society, 2002; 124: 14524-14525.

Deskur E, Pyrzywarska L, Wilk M, Wysocki H. Exercise-induced increase in hydrogen peroxide plasma levels is diminished by endurance training after myocardial infarction. International Journal of Cardiology, 1998; 67:219-224.

Dzialoszynski LM, Frohlich A, Kuczynski J, Pydzik T, The activity of arylsulfatase in some tumors of the genital organs in women, Arch Immunol Ther Exp (Warsz), 1967, 15:97-99.

Eierusz-Wysocka B, Wysocki H, Byks H, Zozulinska D, Wykretowicz A, Kazmierczak M. Metabolic control quality and free radical activity in diabetic patients. Diabetes Research and Clinical Practice, 1995; 27:193-197.

Forman HJ, Bernardo A, Davies KJA, What is the concentration of hydrogen peroxide 
in blood and plasma? Archives of Biochemistry and Biophysics, 2016; 603:48-53.

GB/T 19106, Solution of sodium hypochlorite, 2013.

GB/T 19104, Peracetic acid solution, 2008.

Ghosh J, Das J, Manna P, Sil PC. Hepatotoxicity of di-(2-ethylhexyl)phthalate is attributed to calcium aggravation ROS-mediated mitochondrial depolarization, and ERK/NF-kB pathway activation. Free Radical Biology and Medicine, 2010; 49: 1779-1791.

Gruber CJ, Tschugguel W, Schneeberger C, Huber JC. Production and actions of estrogens. The New England Journal of Medicine, 2002; 346:340-352.

Halliwell B, Clement MV, Long LH. Hydrogen peroxide in the human body. FEBS Letters, 2000; 486: 10-13.

Hidalgo E, Bartolome R, Dominguez C., Cytotoxicity mechanisms of sodium hypochlorite in cultured human dermal fibroblasts and its bactericidal effectiveness. Chemico-Biological Interactions, 2002; 139: 265-268.

Huang Q, Dawson RA, Pegg DE, Kearney JN, Macneil S, Use of peracetic acid to sterilize human donor skin for production of acellular dermal matrices for clinical use. Wound Repair and Regeneration, 2004; 12:276-287.

Hugo WB, A brief history of heat, chemical and radiation preservation and disinfection. International Biodegradation \& Biodegradation, 1995; 36:197-217.

Kazmierczak M, Wysocki H, Wykretowicz A, Minczykowski A. Estimation of hydrogen peroxide plasma levels in patients evaluated for coronary heart disease using dipyridamole infusion followed by SPECT. Coronary Artery Disease, 1995; 6: 65-69.

Kay VR, Chambers C, Foster WG. Reproductive and developmental effects of phthalate diesters in females. Critical Reviews in Toxicology, 2013; 43:200-219.

Koide Y, Urano Y, Hanaoka K, Terai T, Nagano T. Development of an Si-Rhodamine-based far-red to near-infrared fluorescence probe selective for hypochlorous acid and its applications for biological imaging. Journal of American Chemical Society, 2011; 133: 5680-5682.

Lacy F, O'Connor DT, Schmid-Schonbein GW. Plasma hydrogen peroxide production in hypertensives and normotensive subjects at genetic risk of hypertension. Journal of hypertension, 1998; 16:291-303.

Lacy F, Kailasan MT, O’Connor DT, Schmid-Schonbein GW, Parmer RJ. Plasma hydrogen peroxide production in human essential hypertension. Role of heredity, gender, and ethnicity. Hypertension, 2000; 36: 878-884.

Li D, Sun WP, Zhou YM, Liu QG, Zhou SS, Luo N, Bian FN, Zhao ZG, Guo M. Chronic niacin overload may be involved in the increased prevalence of obesity in US children. World Journal of Gastroenterology, 2010; 16: 2378-2387.

Liu ZH, Kanjo Y, Mizutani S. Urinary excretion rates of natural estrogens and androgens from humans, and their occurrence and fate in the environment: a review. Science of the Total Environment, 2009; 407: 4975-4985.

Liu ZH, Kanjo Y, Mizutani S. A review of phytoestrogens: their occurrence and fate in the environment. Water Research, 2010; 44:567-577.

Loo AEK, Halliwell B. Effects of hydrogen peroxide in a keratinocyte-fibroblast 
co-culture model of wound healing. Biochemical and Biophysical Research Communications, 2012; 423: 253-258.

Luo JH, Hendryx M. Relationship between blood cadmium, lead and serum thyroid measures in US adults-the National and Nutrition Examination Survey (NHANES) 2007-2010. International Journal of Environmental Health Research, 2014; 24:125-136.

Luo Q, Liu ZH, Yin H, Dang Z, Wu PX, Zhu NW, Lin Z, Liu Y. Migration and potential risk of trace phthalates in bottled water: A global situation. Water Research, 2018; 147: 362-372.

Luo Q, Liu ZH, Yin H, Dang Z, Wu PX, Zhu NW, Lin Z, Liu Y. Global review of phthalates in edible oil: An emerging and nonnegligible exposure source to human. Science of the Total Environment, 2020; 704: 135369.

Mariana M, Feiteiro J, Verde I, Cairrao E. The effects of phthalates in the cardiovascular and reproductive systems: A review. Environment International, 2016; 94: 758-776.

Mates JM, Segura JA, Alonsom FJ, Marquez J. Roles of dioxins and heavy metals in cancer and neurological diseases using ROS-mediated mechanisms. Free Radical Biology and Medicine, 2010; 49: 1328-1342.

Mathieu-Denoncourt J, Wallace SJ, de Solla SR, Langlois VS. Plasticizer endocrine disruption: Highlighting developmental and reproductive effects in mammals and non-mammalian aquatic species. General and Comparative Endocrinology, 2015; 219:74-88.

Matovic V, Buha A, Dukic-Cosic D, Bulat Z. Insight into the oxidative stress induced by lead and/or cadmium in blood, liver and kidneys. Food and Chemical Toxicology, 2015; 78: 130-140.

Melnick RL. Introduction-workshop on characterizing at environmental exposure levels. Environmental Health Perspectives, 1999; 107(suppl): 603-604.

Parenti G, Meroni G, Ballabio A, The sulfatase gene family, Current Opinion in Genetics \& Development, 1997;7:386-391.

Paschoalini AL, Savassi LA, Arantes FP, Rizzo E, Bazzoli N. Heavy metals accumulation and endocrine disruption in prochlodus argentecis from a polluted neotropical river. Ecotoxicology and Environmental Safety, 2019; 169:539-550.

Perez-Martinex P, Garcia-Quintana JM, Yubero-Serrano EM, Tasset-Cuevas I Tunez, I, Garcia-Rios A, Delgado-Lista J, Marin C, Perez-Jimenez F, Roche HM, Lopez-Miranda J. Postprandial oxidative stress is modified by dietary fat: evidence from a human intervention study. Clinical Science, 2010; 119:251-261.

Posey LE, Morgan LR. Urine enzyme activities in patients with transitional cell carcinoma of the bladder, Clin Chim Acta, 1977, 74 (1) :7-10.

Rath VL, Verdugo D, Hemmerich S. Sulfotransferase structural biology and inhibitor discovery. Drug Discovery Today, 2004; 9: 1003-1011.

Reed MJ, Purohit A, Woo LWL, Newman SP, Potter BVL. Steroid sulfatase: molecular biology, regulation, and inhibition. Endocrine Reviews, 2005; 26: 171-202.

Sato Y, Ogino K, Sakano N, Wang DH, Yoshida J, Akazawa Y, Kanbara S, Inoue K, 
Kubo M, Takahashi H. Evaluation of urinary hydrogen peroxide as an oxidative stress biomarker in a healthy Japanese population. Free Radical Research, 2013;47:181-191.

Shen C, Wang Y, Shen Q, Wang L, Lu Y, Li X, Wei J. Di-(2-ethylhexyl)phthalate induced the growth inhibition and oxidation damage in the microalga chlorella vulgaris. IOP conference series: earth and environmental science, 2019; 227:052054.

Stasenko S, Bradford EM, Piasek M, Henson MC, Varnai VM, Jurasovic J, Kusec V. Metals in human placenta: focus on the effects of cadmium on steroid homones and leptin. Journal of Applied Toxicology, 2010; 30:242-253.

Szymanska-Chabowska A., Beck A, Poreba R, Andrezejak R, Antonowicz-Juchniewicz J. Evaluation of DNA damage in people occupationally exposed to arsenic and some heavy metals. Polish Journal of Environmental Studies, 2009; 18:1131-1139.

Taha M, Almandil NB, Rashid U, Ali M, Ibrahim M, Gollapalli M, Mosaddik A, Khan KM. 2,5-disubstituted thiadiazoles as potent beta-glucuronidase inhibitors; Synthesis, in vitro and in silico studies, Bioorganic Chemistry, 2019a, 91:103126.

Taha M, Imran S, Alomari M, Rahim F, Wadood A, Mosaddik A, Uddin N, Gollapalli M, Alqahtani MA, Bamarouf YA. Synthesis of oxadiazole-coupled-thiadiazole derivatives as a potent beta-glucuronidase inhibitors and their molecular docking study, Bioorganic \& Medicinal Chemistry. 2019b; 27: 3145-3155.

Tsukimori K, Yoshitomi T, Morokuma S, Fukushima K, Wake N. Serum uric acid levels correlate with plasma hydrogen peroxide and protein carbonyl levels in preeclampsia. American Journal of hypertensions, 2008; 21: 1343-1346.

U.S.EPA. Special report on environmental endocrine disruption: An effects as assessment and analysis. EPA/630/r-96/012, 1997.

Varma SD, Devamanoharan PS. Hydrogen peroxide in human blood. Free Radical Research Communications, 1990; 4: 125-131.

Walaszek Z, Potential use of D-glucaric acid derivatives in cancer prevention. Cancer Letters, 1990; 54: 1-8.

Wang H, Liu ZH, Tang Z, Zhang J, Yin H, Dang Z, Wu PX, Liu Y. Bisphenol analogues in Chinese bottled water: Quatification and potential risk analysis. Science of the Total Environment, 2020; 713: 136583.

Yamamoto Y, Brodsky MH, Baker JC, Ames BN. Detection and characterization of lipid hydroperoxides at picomole levels by high-performance liquid chromatography. Analytical Biochemistry, 1987; 160:7-13.

Yamamoto Y, Ames BN. Detection of lipid hydroperoixdes and hydrogen peroxide at picamole levels by an HPLC and isoluminol chemiluminescence assay. Free Radical Biology \& Medicine, 1987; 3:359-361.

Yap YW, Whiteman M, Cheung NS. Chlorinative stress: An under appreciated mediator of neurodegeneration? Cellular Signalling, 2007; 19: 219-228.

Yuan SF, Liu ZH, Lian HX, Yang C, Lin Q, Yin H, Dang Z. Simultaneous determination of estrogenic odorant alkylphenols, chlorophenols, and their 
derivatives in water using online headspace solid phase microextraction coupled with gas chromatography-mass spectrometry, Environmental Science \& Pollution Research, 2016; 23:19116-19125.

Yuan SF, Liu ZH, Lian HX, Yang C, Lin Q, Yin H, Dang Z. Simultaneous determination of eleven estrogenic and odorous chloro- and bromo-phenolic compounds in surface water through an automated online headspace SPME followed by on-fiber derivatization coupled with GC-MS, Analytical Methods, 2017; 9(33):4819-4827.

Zembron-Lacny A, Naczk M, Gajewski M, Ostapiwk-Karolczuk J, Dziewiecka H, Kasperska A, Szyszka K. Changes of muscle-derived cytokines in relation to thiol redox status and reactive oxygen and nitrogen species. Physiology Research, 2010; 59:945-951.

Zhang J, Liu ZH, Zhong SS, Wang H, Caidan BM, Yin H, Dang Z. Strategy for effective inhibition of arylsulfatase/ $\beta$-glucuronidase to prevent deconjguation of sulfate and glucuronide conjugates in wastewater during sample collection and storage. Science of the Total Environment, 2020, 703:135536.

Zhao Y, Boyd JM, Sawyer MB, Li XF. 2014. Liquid chromatography tandem mass spectrometry determination of free and conjugated estrogens in breast cancer patients before and after exemestane treatment. Analytica Chimica Acta 806:172-179. 